\title{
Effect of NPK Media Concentrations on In Vitro Potato Tuberization of Cultivars Nicola and Russet Burbank
}

\author{
Abdellah Radouani • Florian I. Lauer
}

Published online: 12 March 2015

(C) The Author(s) 2015. This article is published with open access at Springerlink.com

\begin{abstract}
Our objective was to test whether the NPK levels in commonly used Murashige and Skoog (MS) media are optimal for microtuberiztion for the two cultivars tested. Two $\mathrm{N}\left(\mathrm{N}_{1}=841\right.$ and $\left.\mathrm{N}_{2}=1418 \mathrm{mg} \mathrm{L}^{-1}\right)$; three $P\left(\mathrm{P}_{1}=39, \mathrm{P}_{2}=76.9\right.$ and $\mathrm{P}_{3}=115 \mathrm{mg} \mathrm{L}^{-1}$; and two $\mathrm{K}$ $\left(\mathrm{K}_{1}=784\right.$ and $\left.\mathrm{K}_{2}=1518 \mathrm{mg} \mathrm{L}^{-1}\right)$ media concentrations were evaluated for microtuberization. Higher levels of $\mathrm{N}_{2} \mathrm{P}_{3} \mathrm{~K}_{2}$ were more effective for microtuberization than the lower levels of $\mathrm{N}_{1} \mathrm{P}_{1} \mathrm{~K}_{1}$ in standard MS media. $\mathrm{N}_{2} \mathrm{P}_{3} \mathrm{~K}_{2}$ was the best concentration for all yield components studied, tuber number, tuber weight, and stem and root weight. For the two cultivars, our results suggest that higher NPK levels than those in MS media would enhance in vitro microtuberization, and that optimum NPK levels could vary for cultivars.
\end{abstract}

Resumen Nuestro objetivo fue probar si los niveles de NPK en el medio comúnmente usado de Murashige y Skoog son óptimos para la microtuberización en las dos variedades probadas. Se evaluaron dos concentraciones de $\mathrm{N}$ en el medio $\left(\mathrm{N} 1=841\right.$ y N2=1418 $\left.\mathrm{mg} \mathrm{L}^{-1}\right)$; tres de $\mathrm{P}(\mathrm{P} 1=39, \mathrm{P} 2=76.9 \mathrm{y}$ $\left.\mathrm{P} 3=115 \mathrm{mg} \mathrm{L}^{-1}\right)$; $\mathrm{y}$ dos de $\mathrm{K}\left(\mathrm{K} 1=784\right.$ y K2 $\left.=1518 \mathrm{mg} \mathrm{L}^{-1}\right)$ para la microtuberización. Los niveles más altos de N2P3K3 fueron más efectivos que los más bajos N1P1K1 para tal fin en el medio estándar MS (Physiologia Plantarum 15:473-497, 1962). N2P3K2 fue la mejor concentración para todos

\footnotetext{
A. Radouani $(\triangle)$

Domaines Royaux El Boura, P.O.Box 62, Taroudant 83 000, Morocco

e-mail: a.radouani@menara.ma

F. I. Lauer

Department of Horticultural Science, University of MN,

1736 Tatum St., St. Paul, MN 55113, USA

e-mail: lauer002@tc.umn.edu
}

los componentes de rendimiento estudiados, número y peso de tubérculo, y peso de tallo y raíz. Para las dos variedades, nuestros resultados sugieren que niveles más altos de NPK que los del medio MS estimularían la microtuberización in vitro, y que los niveles óptimos de NPK podrían variar para los cultivares. De las combinaciones de medios NPK probadas, N2P3K2 fue la superior de todas las evaluadas.

Keywords Microtubers · Nitrogen · Phosphorus · Potassium $\cdot$ Microtuberization

\section{Introduction}

Little attention has been paid to the effect of various rates of $\mathrm{N}$, $\mathrm{P}$, and $\mathrm{K}$ in the nutrient medium, all of which play a key role in induction of microtuberization (Wang and $\mathrm{Hu}$ 1985). N interacts with genotype (Sarkar and Naik 1998) and sugar (Ranalli $1997)$ in the nutrient medium. High concentration of $\mathrm{N}\left(60 \mathrm{~L}^{-1}\right)$ inhibited coumarin-induced tuberization (Stallknecht and Farnsworth 1979; Wattimena 1983). Garner (1987) suggested a possible inhibitory effect on tuberization with an increase from 1x to 2x MS (Murashige and Skoog 1962) N concentration. In contrast, high $\mathrm{N}$ level did not influence cytokinininduced microtuberization (Palmer and Smith 1969; Wang and $\mathrm{Hu}$ 1982; Estrada et al. 1986; Sarkar and Naik 1998).

Reducing $\mathrm{N}$ levels in nutrient medium free of growth regulators from $1 \mathrm{x}$ MS to $0.1 \mathrm{x}$ MS reduced tuber number (Garner 1987; Garner and Blake 1989). Cytokinin-induced nutrient medium with reduced $\mathrm{N}$ increased tuber number but decreased tuber weight (Sarkar and Naik 1998). Zarrabeitia et al. (1997) found that low N, 19-23 L $\mathrm{L}^{-1}$, produced optimum results in micropropagation, and there was a "carry-over" effect of $\mathrm{N}$ content in the micropropagation medium on 
subsequent tuberization. A lower concentration of N, $23 \mathrm{~L}^{-1}$, induced earlier tuber initiation.

With respect to K and P, Naik and Sarkar (1998) reported K had a positive effect on microtuber size. Maximum microtuber size and harvest index were obtained with a nutrient medium concentration of $40 \mu \mathrm{M}$ potassium. The impact of $\mathrm{P}$ on microtuberization has received little attention.

All of the previous reports evaluated one or two elements at the same time. There were no reports on the three macroelements evaluated simultaneously. Observations in our laboratory (unpublished data) suggested depletion of $\mathrm{P}$ and low levels of $\mathrm{N}$ and $\mathrm{K}$ in the Murashige and Skoog (1962) culture medium at harvest; hence, $2 \mathrm{x}$ and 3x MS P concentrations and $2 \mathrm{x}$ MS $\mathrm{N}$ and $\mathrm{K}$ concentrations were used in our experiment.

\section{Materials and Methods}

Plant Materials

Disease-tested plantlets of Nicola and Russet Burbank originated from the germplasm bank of "Laboratoire Agronomique EL BOURA" located in Taroudant, Morocco. Two methods of propagation were used depending on final use of the plantlets; either for micropropagation or for microtuberization (Radouani and Lauer 2015). Microprogation was made from single-middle-node cuttings on solid medium. Mother plantlets were 3 weeks old. These were derived from four subcultures made at three-week intervals. The MS nutrient medium was supplemented with $\mathrm{NaH}_{2} \mathrm{PO}_{4}\left(148 \mathrm{mg} \mathrm{L}^{-1}\right)$, thiamine $\mathrm{HCl}\left(0.4 \mathrm{mg} \mathrm{L}^{-1}\right)$, myo-inositol (100.0 $\left.\mathrm{mg} \mathrm{L}^{-1}\right)$, and sucrose $\left(30 \mathrm{~g} \mathrm{~L}^{-1}\right)$. The solidifying agent was Phytagel $\left(1.5 \mathrm{~g} \mathrm{~L}^{-1}\right)$.

Table 1 Effect of 12 nitrogen, phosphorus and potassium nutrient media combinations on microtuberization of Nicola and Russet Burbank

\begin{tabular}{|c|c|c|c|c|c|c|c|}
\hline Cultivar & Combination & TTN & Combination & TTW ( & (g) & Combination & SRW (g) \\
\hline \multirow[t]{12}{*}{ Nicola } & $\mathrm{N}_{2} \mathrm{P}_{3} \mathrm{~K}_{2}$ & $68.3 \mathrm{a}$ & $\mathrm{N}_{2} \mathrm{P}_{3} \mathrm{~K}_{2}$ & 114.1 & & $\mathrm{~N}_{2} \mathrm{P}_{3} \mathrm{~K}_{2}$ & $91.2 \mathrm{a}$ \\
\hline & $\mathrm{N}_{1} \mathrm{P}_{2} \mathrm{~K}_{2}$ & $66.5 \mathrm{a} \mathrm{b}$ & $\mathrm{N}_{2} \mathrm{P}_{3} \mathrm{~K}_{1}$ & 103.6 & $a b$ & $\mathrm{~N}_{2} \mathrm{P}_{2} \mathrm{~K}_{2}$ & $77.1 \quad b$ \\
\hline & $\mathrm{N}_{1} \mathrm{P}_{1} \mathrm{~K}_{2}$ & $65.0 \mathrm{abc}$ & $\mathrm{N}_{2} \mathrm{P}_{2} \mathrm{~K}_{2}$ & 103.4 & $a b$ & $\mathrm{~N}_{1} \mathrm{P}_{2} \mathrm{~K}_{2}$ & $69.3 \mathrm{bc}$ \\
\hline & $\mathrm{N}_{1} \mathrm{P}_{1} \mathrm{~K}_{1}$ & $63.0 \mathrm{a} \mathrm{b} \mathrm{c}$ & $\mathrm{N}_{2} \mathrm{P}_{2} \mathrm{~K}_{1}$ & 95.7 & $a b c$ & $\mathrm{~N}_{2} \mathrm{P}_{3} \mathrm{~K}_{1}$ & $69.2 \mathrm{bc}$ \\
\hline & $\mathrm{N}_{2} \mathrm{P}_{3} \mathrm{~K}_{1}$ & $57.2 \mathrm{abc}$ & $\mathrm{N}_{2} \mathrm{P}_{1} \mathrm{~K}_{1}$ & 88.1 & $\mathrm{bc}$ & $\mathrm{N}_{1} \mathrm{P}_{3} \mathrm{~K}_{2}$ & $65.7 \mathrm{bc}$ \\
\hline & $\mathrm{N}_{1} \mathrm{P}_{3} \mathrm{~K}_{2}$ & $57.2 \mathrm{abc}$ & $\mathrm{N}_{1} \mathrm{P}_{2} \mathrm{~K}_{2}$ & 83.3 & $\mathrm{bc}$ & $\mathrm{N}_{1} \mathrm{P}_{1} \mathrm{~K}_{2}$ & $65.0 \mathrm{bc}$ \\
\hline & $\mathrm{N}_{2} \mathrm{P}_{2} \mathrm{~K}_{2}$ & $56.5 \mathrm{abc}$ & $\mathrm{N}_{2} \mathrm{P}_{1} \mathrm{~K}_{2}$ & 82.6 & $\mathrm{bc}$ & $\mathrm{N}_{1} \mathrm{P}_{1} \mathrm{~K}_{1}$ & 58.6 \\
\hline & $\mathrm{N}_{1} \mathrm{P}_{3} \mathrm{~K}_{1}$ & $56.2 \mathrm{abc}$ & $\mathrm{N}_{1} \mathrm{P}_{1} \mathrm{~K}_{1}$ & 82.0 & $\mathrm{bc}$ & $\mathrm{N}_{2} \mathrm{P}_{2} \mathrm{~K}_{1}$ & 58.3 \\
\hline & $\mathrm{N}_{2} \mathrm{P}_{1} \mathrm{~K}_{1}$ & $50.7 \mathrm{a} \mathrm{b} \mathrm{c}$ & $\mathrm{N}_{1} \mathrm{P}_{3} \mathrm{~K}_{2}$ & 78.6 & $\mathrm{bc}$ & $\mathrm{N}_{2} \mathrm{P}_{1} \mathrm{~K}_{1}$ & 57.1 \\
\hline & $\mathrm{N}_{1} \mathrm{P}_{2} \mathrm{~K}_{1}$ & $50.0 \mathrm{a} \mathrm{b} \mathrm{c}$ & $\mathrm{N}_{1} \mathrm{P}_{2} \mathrm{~K}_{1}$ & 74.0 & $\mathrm{c}$ & $\mathrm{N}_{1} \mathrm{P}_{3} \mathrm{~K}_{1}$ & 55.6 \\
\hline & $\mathrm{N}_{2} \mathrm{P}_{2} \mathrm{~K}_{1}$ & $46.3 \mathrm{~b} \mathrm{c}$ & $\mathrm{N}_{1} \mathrm{P}_{3} \mathrm{~K}_{1}$ & 73.2 & $\mathrm{c}$ & $\mathrm{N}_{1} \mathrm{P}_{2} \mathrm{~K}_{1}$ & 53.9 \\
\hline & $\mathrm{N}_{2} \mathrm{P}_{1} \mathrm{~K}_{2}$ & $45.0 \quad \mathrm{c}$ & $\mathrm{N}_{1} \mathrm{P}_{1} \mathrm{~K}_{2}$ & 72.2 & $\mathrm{c}$ & $\mathrm{N}_{2} \mathrm{P}_{1} \mathrm{~K}_{2}$ & 53.9 \\
\hline \multirow[t]{12}{*}{ Russet Burbank } & $\mathrm{N}_{2} \mathrm{P}_{3} \mathrm{~K}_{2}$ & $67.8 \mathrm{a}$ & $\mathrm{N}_{2} \mathrm{P}_{3} \mathrm{~K}_{2}$ & 145.2 & & $\mathrm{~N}_{2} \mathrm{P}_{3} \mathrm{~K}_{2}$ & $77.6 \mathrm{a}$ \\
\hline & $\mathrm{N}_{2} \mathrm{P}_{2} \mathrm{~K}_{2}$ & $57.7 \mathrm{a} \mathrm{b}$ & $\mathrm{N}_{2} \mathrm{P}_{2} \mathrm{~K}_{2}$ & 125.2 & $\mathrm{~b}$ & $\mathrm{~N}_{1} \mathrm{P}_{3} \mathrm{~K}_{2}$ & $72.9 \mathrm{a} \mathrm{b}$ \\
\hline & $\mathrm{N}_{1} \mathrm{P}_{2} \mathrm{~K}_{2}$ & $55.5 \mathrm{abc}$ & $\mathrm{N}_{1} \mathrm{P}_{2} \mathrm{~K}_{2}$ & 121.2 & $\mathrm{bc}$ & $\mathrm{N}_{1} \mathrm{P}_{2} \mathrm{~K}_{2}$ & $71.7 \mathrm{a} \mathrm{b}$ \\
\hline & $\mathrm{N}_{1} \mathrm{P}_{1} \mathrm{~K}_{2}$ & $49.8 \mathrm{~b} \mathrm{c}$ & $\mathrm{N}_{1} \mathrm{P}_{3} \mathrm{~K}_{2}$ & 119.5 & $\mathrm{bc}$ & $\mathrm{N}_{2} \mathrm{P}_{2} \mathrm{~K}_{2}$ & $68.0 \mathrm{a} \mathrm{b}$ \\
\hline & $\mathrm{N}_{1} \mathrm{P}_{3} \mathrm{~K}_{2}$ & $49.0 \quad \mathrm{~b} \mathrm{c}$ & $\mathrm{N}_{1} \mathrm{P}_{3} \mathrm{~K}_{1}$ & 113.8 & $\mathrm{bc}$ & $\mathrm{N}_{1} \mathrm{P}_{2} \mathrm{~K}_{1}$ & $65.0 \mathrm{a} \mathrm{b} c$ \\
\hline & $\mathrm{N}_{2} \mathrm{P}_{3} \mathrm{~K}_{1}$ & $48.7 \mathrm{~b} \mathrm{c}$ & $\mathrm{N}_{2} \mathrm{P}_{2} \mathrm{~K}_{1}$ & 108.0 & $\mathrm{bcd}$ & $\mathrm{N}_{1} \mathrm{P}_{3} \mathrm{~K}_{1}$ & $63.9 \mathrm{bc}$ \\
\hline & $\mathrm{N}_{1} \mathrm{P}_{3} \mathrm{~K}_{1}$ & $48.2 \mathrm{~b} \mathrm{c}$ & $\mathrm{N}_{1} \mathrm{P}_{2} \mathrm{~K}_{1}$ & 106.5 & $\mathrm{bcd}$ & $\mathrm{N}_{1} \mathrm{P}_{1} \mathrm{~K}_{2}$ & $63.5 \mathrm{bc}$ \\
\hline & $\mathrm{N}_{1} \mathrm{P}_{2} \mathrm{~K}_{1}$ & $47.8 \quad \mathrm{~b} \mathrm{c}$ & $\mathrm{N}_{2} \mathrm{P}_{3} \mathrm{~K}_{1}$ & 104.5 & $\mathrm{bcd}$ & $\mathrm{N}_{2} \mathrm{P}_{3} \mathrm{~K}_{1}$ & 55.5 \\
\hline & $\mathrm{N}_{2} \mathrm{P}_{1} \mathrm{~K}_{2}$ & $44.8 \quad \mathrm{~b} \mathrm{c}$ & $\mathrm{N}_{1} \mathrm{P}_{1} \mathrm{~K}_{2}$ & 97.9 & $\mathrm{~cd}$ & $\mathrm{~N}_{2} \mathrm{P}_{2} \mathrm{~K}_{1}$ & 52.5 \\
\hline & $\mathrm{N}_{2} \mathrm{P}_{1} \mathrm{~K}_{1}$ & $42.5 \mathrm{~b} \mathrm{c}$ & $\mathrm{N}_{2} \mathrm{P}_{1} \mathrm{~K}_{1}$ & 87.6 & $\mathrm{de}$ & $\mathrm{N}_{2} \mathrm{P}_{1} \mathrm{~K}_{1}$ & 52.5 \\
\hline & $\mathrm{N}_{1} \mathrm{P}_{1} \mathrm{~K}_{1}$ & $39.3 \mathrm{bc}$ & $\mathrm{N}_{2} \mathrm{P}_{1} \mathrm{~K}_{2}$ & 85.1 & $\mathrm{de}$ & $\mathrm{N}_{2} \mathrm{P}_{1} \mathrm{~K}_{2}$ & 51.3 \\
\hline & $\mathrm{N}_{2} \mathrm{P}_{2} \mathrm{~K}_{1}$ & $38.5 \quad \mathrm{c}$ & $\mathrm{N}_{1} \mathrm{P}_{1} \mathrm{~K}_{1}$ & 70.7 & $\mathrm{e}$ & $\mathrm{N}_{1} \mathrm{P}_{1} \mathrm{~K}_{1}$ & 50.9 \\
\hline
\end{tabular}

TTN Total Tuber Number, TTW Total Tuber Weight, and SRW Stem and Root Weight

$\mathrm{N}_{1}=841 \mathrm{mg} \mathrm{L}^{-1}, \mathrm{~N}_{2}=1418 \mathrm{mg} \mathrm{L}^{-1}$

$\mathrm{P}_{1}=38.69 \mathrm{mg} \mathrm{L}^{-1}, \mathrm{P}_{2}=76.9 \mathrm{mg} \mathrm{L}^{-1}, \mathrm{P}_{3}=115 \mathrm{mg} \mathrm{L}^{-1}$

$\mathrm{K}_{1}=783.65 \mathrm{mg} \mathrm{L}^{-1}, \mathrm{~K}_{2}=1518.37 \mathrm{mg} \mathrm{L}^{-1}$

Within the same cultivar column, means followed by the same letter are not different at $P=0.05$ 
In vitro propagation of plantlets for microtuber production was done from whole plantlets. The plantlets were uniformly trimmed to four nodes excluding the shoot apex and basal node. The nutrient medium was the same as for micropropagation except for the lack of Phytagel. This medium was used during the "growth phase" defined as the time from initiation of the culture until tuberization. This phase was 5 weeks long.

The "tuberization phase" was 16 weeks long, after which tubers were counted and weighed. For the tuberization phase, the liquid medium for growth was removed and replaced with a similar nutrient medium, in which sucrose concentration was increased from 30 to $80 \mathrm{~g} \mathrm{~L}^{-1}$ and $\mathrm{NaH}_{2} \mathrm{PO}_{4}$ eliminated. Twelve NPK combinations were used including two concentrations of nitrogen, $\mathrm{N}_{1}=841$ and $\mathrm{N}_{2}=1418 \mathrm{mg} \mathrm{L}^{-1}$; three concentrations of phosphorus, $\mathrm{P}_{1}=39, \mathrm{P}_{2}=76.9$ and $\mathrm{P}_{3}=115 \mathrm{mg} \mathrm{L}^{-1}$; and two concentrations of potassium, $\mathrm{K}_{1}=784$ and $\mathrm{K}_{2}=$ $1518 \mathrm{mg} \mathrm{L}^{-1}$. All of these 12 nutrient media were supplemented with: thiamine $\mathrm{HCl}, 0.4 \mathrm{mg} \mathrm{L}^{-1}$; myo-inositol, $100 \mathrm{mg} \mathrm{L}^{-1}$; sucrose, $80 \mathrm{~g} \mathrm{~L}^{-1}$; and coumarin, $25 \mathrm{mg} \mathrm{L}^{-1}$. $\mathrm{N}_{1} \mathrm{P}_{1} \mathrm{~K}_{1}$ represents levels of N, P and $\mathrm{K}$ found in standard MS media, and served as the control in this experiment.

The $\mathrm{pH}$ of all nutrient media was adjusted to 5.8 before autoclaving for $15 \mathrm{~min}$ at $121^{\circ} \mathrm{C}$ and $1.5 \mathrm{~kg} / \mathrm{cm}^{2}$.

\section{Culture Vessels}

Jars (650 ml volume) were used for solid medium and $250 \mathrm{ml}$ Erlenmeyer flasks for liquid medium. The nutrient volume in jars for micropropagation was $60 \mathrm{ml}$ during the first 5 weeks and $150 \mathrm{ml}$ for microtuberization thereafter for 16 weeks. Jars were closed with plastic screw-top lids and flasks closed with cotton plugs topped with heavy-duty aluminum foil.

\section{Culture Incubation Conditions}

Three growth rooms, $5.20 \mathrm{~m}$ long, $3.95 \mathrm{~m}$ wide and $3.15 \mathrm{~m}$ high, were used. These rooms were equipped with shelves and fluorescent strip lights set to provide $85 \mu \mathrm{mol} \mathrm{m}^{-2} \mathrm{~s}^{-1}$ PAR (photosynthetically active radiation) at the plant level on each shelf. A $16 \mathrm{~h}$ photoperiod was provided during the growth phase and total darkness during the tuberization phase. The vessels were gently agitated during the tuberization phase. Room temperature was set to $24{ }^{\circ} \mathrm{C}$ and controlled by an air conditioning system allowing a variation of $\pm 1{ }^{\circ} \mathrm{C}$ from the programmed temperature. These aseptic rooms were equipped with an aseptic fresh air injector. The injector was programmed to inject air into the growth rooms every $2 \mathrm{~h}$. The purification of air was done in three steps:

1. Prefiltration with Interpak H filter, $490 / 540 / 500 \mathrm{~mm}$;

2. Irradiation with ultra violet light, TUV $15 \mathrm{~W} \mathrm{G15} \mathrm{T8;} \mathrm{and}$

3. Final filtration with an MP99 filter $(305 \times 305 \times 6 \mathrm{~mm}$ pore size, $0.12 \mu \mathrm{m})$.

\section{Data Analysis}

The experimental unit consisted of four Erlenmeyer flasks with four explants each. Tuber number (TTN), tuber weight (TTW), and stem and root weight (SRW) for each combination were recorded and statistically analyzed to identify the best nutrient medium for potato tuberization. The results for all traits were presented by cultivar and by interactions, if any.

Data were analyzed using SAS. Randomization was done using STATITCF software. Main effects were tested by ANOVA and mean were separated using the StudentNewman-Keuls test.

\section{Results and Discussion}

For both cultivars, $\mathrm{N}_{2} \mathrm{P}_{3} \mathrm{~K}_{2}$ ranked first. Statistically, this combination was superior with respect to TTW for Russet Burbank and SRW for Nicola (Table 1). $\mathrm{N}_{1} \mathrm{P}_{1} \mathrm{~K}_{1}$ almost always gave the lowest TTN, TTW, and SRW for Russet Burbank. Except for TTN for Nicola, $\mathrm{N}_{2} \mathrm{P}_{3} \mathrm{~K}_{2}$ was significantly different from the control.

Increased NPK concentrations resulted in an increase of yield components and suggested that microtuberization of potato responds to a higher range of NPK concentrations. The three macroelements interact with each other and with cultivar. In this study the difference between $\mathrm{N}_{2} \mathrm{P}_{3} \mathrm{~K}_{2}$ and $\mathrm{N}_{1} \mathrm{P}_{1} \mathrm{~K}_{1}$ was more distinct for Russet Burbank than for Nicola. The observed interactions suggest that optimal concentrations could be expected to vary for different cultivars.

One could expect that larger microtubers might perform more consistently when planted directly in the field (Tovar et al. 1985 and Wiersema et al. 1987). Perhaps, under some conditions, larger microtubers could replace minitubers in seed potato programs. (Radouani and Lauer 2015).

Open Access This article is distributed under the terms of the Creative Commons Attribution License which permits any use, distribution, and reproduction in any medium, provided the original author(s) and the source are credited.

\section{References}

Estrada, R., P. Tover, and J.H. Dodds. 1986. Induction of in vitro tubers in a broad range of potato genotypes. Plant Cell Tissue and Organ Culture 7: 3-10.

Garner, N. 1987. The development and dormancy of microtubers of potato (Solanum tuberosum L.) produced in vitro. $\mathrm{Ph}$. D. Thesis London University.

Garner, N., and J. Blake. 1989. The induction and development of potato microtubers in vitro on media free of growth regulating substances. Annals of Botany 63: 663-674. 
Murashige, T., and F. Skoog. 1962. A revised medium for rapid growth and bio assays with tobacco tissue cultures. Physiologia Plantarum 15: 473-497.

Naik, P.S., and D. Sarkar. 1998. Effect of potassium on potato microtuber production in vitro. Biologia Plantarum 41: 121-125.

Palmer, C.E., and O.E. Smith. 1969. Cytokinins and Tuber Initiation in the Potato Solanum tuberosum L. Nature 221: 279-280.

Radouani, A., and F.I. Lauer. 2015. Field performance of cultivars Nicola and Russet Burbank micro and minitubers. Submitted for publication. doi 10.1007/s12230-014-9421-9

Ranalli, P. 1997. Innovative propagation methods in seed tuber multiplication programmes. Potato Research 40: 439-453.

Sarkar, D., and P.S. Naik. 1998. Effect of inorganic nitrogen nutrition on cytokinin-induced potato microtuber production in vitro. Potato Research 41: 211-217.

Stallknecht, G.F., and S. Farnsworth. 1979. The effect of nitrogen on the couirmarin-induced tuberization of potato axillary shoots cultured in vitro. American Potato Journal 56: 523530 .
Tovar, P., R. Estrada, L. Schilde-Rentschler, and J. H. Dodds. 1985. Induction of in vitro potato tubers. CIP Circular, International Potato Centre, Lima, Peru. 13:1-4.

Wang, P.J., and C.Y. Hu. 1982. In vitro mass tuberization and virus-free seed-potato production in Taiwan. American Potato Journal 59: 33 37.

Wang, P.J., and C.Y. Hu. 1985. Potato tissue culture and its application in agriculture. In Potato physiology, ed. P.H. Li, 503-577. London: Academic.

Wattimena G.A. 1983. Micropropagation as an alternative technology for potato production in Indonesia $\mathrm{Ph}$. D. Thesis. University of Wisconsin, Madison.

Wiersema, S.G., R. Cabello, P. Tovar, and J.H. Dodds. 1987. Rapid seed multiplication by planting into beds microtubers and in vitro plantlets. Potato Research 30: 117-120.

Zarrabeitia, A., X. Lejarcegui, J. Veramendi, and A.M. Mingo-Castel. 1997. Influence of nitrogen supply on micropropagation and subsequent microtuberization of four potato cultivars. American Potato Journal 74: 369-377. 